\title{
Analyzing of the self reported ICT literacy level of Slovakian and Serbian Students in the higher education
}

\author{
Gabor Kiss ${ }^{1 \mathrm{a}}$, Peter Csiba ${ }^{2}$ \\ ${ }^{1}$ Obuda University, Institute of Mechanical Engineering and Safety Science, Becsi ut 96/b, Budapest \\ H-1034, Hungary \\ ${ }^{2}$ J. Selye University, Department of Mathematics and Informatics, Bratislavská cesta 3322, 945 01, \\ Komárno, Slovakia
}

\begin{abstract}
The students generally use technology for communication in the European Union and outside of the Union. First of all we have to see in this research the ICT knowledge level of the students in the higher education to make decision about the application and retraining methods. It is important to know can we find any difference in ICT literacy between the Slovakian and the Serbian students to see how long is the way to finish the ICT revolution in these countries. On the other hand is it important to see which topic need more attention from the teachers in the high school to give a good knowledge for the student before they go in the higher education. We measured the ICT literacy level with a tool consisting of 15 items (Likert scaled). The data analysis was performed with SPSS software using descriptive statistics and Mann-Whitney test.
\end{abstract}

Keywords: communication, higher education, technology education

\section{Introduction}

Communication and technology have an important role in life and especially in education. Nowadays, students generally use technology for communication. When using technology in education, there may be some communication barriers.

An international comparison analysis tool is an effective way for understanding the situation between two or more different regions of the world. In this sense, literature shows the relevance of analyzing how ICT has been used in education to better understand educational strategies, learning methods and pedagogical techniques in order to effectively apply ICT in the classroom.

The purpose of this study is to identify the levels of ICT Competencies of students from two countries, one in Slovakia (in the EU Commission) and the other in Serbia (out of EU

\footnotetext{
${ }^{a}$ Corresponding author: kiss.gabor@bgk.uni-obuda.hu
} 
Commission). First of all we have to see the ICT knowledge level of the students to make decision about the application and retraining methods.

It is important to know can we find any difference in ICT literacy between the Slovakian and the Serbian students to see how long is the way to finish the ICT revolution in these countries. On the other hand is it important to see which topic need more attention from the teachers in the high school to give a good knowledge for the student before they go in the higher education.

Some earlier research analyzed the ICT literacy of the students in Hungary on different levels [1], [2], [3], [4]. The current research analyses the ICT literacy level of the Serbian and Slovakian students in Higher Education.

\section{Information technology education in Slovakia}

The education of Informatics from the 2 nd grade has been compulsory since the school year of 2008/2009, since the introduction of the school reform but it also appears in the 1st grade as well as in the nursery school curriculum though not as a compulsory subject. It is compulsory to have 1 Informatics lesson a week in the junior section and 0.5 lesson a week in the senior section that can be raised by the schools' own programme. Some schools took the opportunity and increased it to 1 lesson a week. The National Educational Programme does not assign precisely what teachers have to teach in the various grades but announces the school leaving standards to reach at the end of the senior section. So it does not matter if programming is taught in the 6th grade in one school and in the 8th grade in another school; the aim is to reach the school leaving standards. It is part of the educational programme of the school how its students should reach these standards, how many lessons they have a week and at what pace they learn the material; this programme is accepted by the management of the school and its teachers together .

The National Educational Programme divides Informatics into 5 topics (it does not specify the number of lessons):

1. Information around us

2. Communication with the help of the means of the ICT

3. Problem solving, thinking with the help of algorithms

4. Basic principles of the operation of the ICT tools

5. IS society

These 5 topics are then to be divided into the school leaving standards.

\section{Information technology education in Serbia}

The education of Informatics from the 1nd grade has been compulsory since the school year of 2008/2009, following the National Educational Program. It is compulsory to have 1 Informatics lesson a week in the junior section (1st-4th grades) [6], [7]. The learning material include the basic knowledge about computer, Painting program, Word processing, Presentation and e-mail. In the senior section (7th-8th grades) is it just selectable on basic level. The learning material include programming, creating web pages and using multimedia devices. The students have to chance to choose the technical-informatics direction, in that case they spend 2 lessons a week with this subject.

In the secondary grammar school have the students more chance to learn more about ICT. In generally 2 lessons per week is the opportunity the learn ICT, except the students in Art school, where they learn ICT just in the first grade. The learning material include programming, database management and Web 2.0 materials. The students in a specialized secondary grammar schools (natural science and computer science) can spend 12 lessons 
per week with ICT. The problem is the learning material is not parallel with ECDL, it gives not same knowledge [8].

The Serbian students get more ICT lessons from the 1st grade to the end of the secondary grammar school, than the Slovakian students.

Our starting hypothesis after get to know the Serbian and the Slovakian ICT Education, the Serbian Students will reach better results.

\section{Analyzing students' ICT literacy level}

The purpose of this study is to compare the ICT literacy level of students from Slovakian and Serbian universities.

The number of participants: The sample consisted of 440 students, 226 Serbian and 214 Slovakian students (Table 1.)

Table 1. The number of participants by gender and country

\begin{tabular}{|c|c|c|c|}
\hline & Male & Female & Total \\
\hline Serbian & 92 & 134 & 226 \\
\hline Slovakian & 107 & 107 & 214 \\
\hline Total & 199 & 241 & 644 \\
\hline
\end{tabular}

The students filled out a self-reported questionnaire with 15 items. We have used Likert-type rating scales to measure the ICT literacy level of students [9].

Liker scales are commonly used by self-reported questionnaire, providing a range of responses to a given question or statement [10]. There were 4 categories of response: $1=$ basic level; 2 = medium; 3 = advanced, 4 = ,master”.

The reliability of the questionnaire obtained by the technique of Cronbach- $\alpha$ was 0.927 it means the reliability of the questionnaire is very good.

\subsection{The results of Independent Samples Mann-Whitney U test}

The Likert scale is ordinary scale, and as such we can calculate mean, min, max, median, modus, std. dev. etc. We can use the nonparametic tests where we need ordinary variables. We have two independent samples so we could use the Mann-Whitney-Wilcoxon test for 2 samples [11]. The Mann-Whitney-Wilcoxon test seems better choice versus $t$ test by Likerttype data [12], because it is testing the medians of the samples.

We used the Mann-Whitney independent sample U test of SPSS to compare the means of scores taken by the students. Monitoring was held on $\mathrm{p}=5 \%$ significancy level in the whole analyzing process.

We used 3 different ways of comparison: by countries, by gender and by gender in Slovakia or in Serbia

\subsubsection{The results of Independent Samples Mann-Whitney U test by countries}

If we summarize the scores of all items and make the comparison can we see the ICT literacy level of students by countries. The result of Mann-Whitney $U$ test on the total scores has shown significant difference between the 2 group of students by ICT literacy, $\mathrm{p}=0.000$.

We calculated the mean scores by items and also calculated the difference between them grouped by countries. Then we can made analysis process with Mann-Whitney U test (Table 2.). 
Table 2. The results of Independent Samples Mann-Whitney U test by countries

\begin{tabular}{|c|l|c|c|c|}
\hline \multirow{2}{*}{ Number of item } & \multicolumn{1}{|c|}{ Item } & $\begin{array}{c}\text { Serbian } \\
\text { (Mean score) }\end{array}$ & $\begin{array}{c}\text { Slovakian } \\
\text { (Mean score) }\end{array}$ & $\mathrm{p}$ \\
\hline 1 & Handling Operating System (OS) & 2,66 & 2,10 & 0,00 \\
\hline 2 & Word processor & 3,03 & 2,36 & 0,00 \\
\hline 3 & Spreadsheet & 2,60 & 1,93 & 0,00 \\
\hline 4 & Database Management & 2,04 & 1,56 & 0,00 \\
\hline 5 & Multimedia & 2,57 & 2,06 & 0,00 \\
\hline 6 & Software specific to my degree & 2,08 & 1,71 & 0,00 \\
\hline 7 & Using documentary bases (Such as EBSCO) & 2,03 & 1,57 & 0,00 \\
\hline 8 & Web Browsing & 3,24 & 2,80 & 0,00 \\
\hline 9 & Internet Communication & 3,31 & 2,77 & 0,00 \\
\hline 10 & Internet Safety & 2,65 & 2,05 & 0,00 \\
\hline 11 & Website design & 1,82 & 1,38 & 0,00 \\
\hline 12 & Using learning platforms & 2,69 & 1,28 & 0,00 \\
\hline 13 & Image Editing & 2,03 & 2,06 & 0,00 \\
\hline 14 & Video Editing & 1,73 & 1,61 & 0,00 \\
\hline 15 & Creating simulations and animations & 1,31 & 0,00 \\
\hline
\end{tabular}

According to the table we can see the scores of the students from different countries; we can see that the subjective ICT literacy level of Serbian students is significant higher than the Slovakian students by every items. It means the Serbian students can take the advantages of the higher number of ICT lessons.

\subsubsection{The results of Independent Samples Mann-Whitney $U$ test by gender}

We have seen the Serbian students reached significant higher scores by every items. It is important to see, the difference is same by the genders too, or not. We calculated the mean scores by items and also calculated the difference between them grouped by genders. Then can we make analysis process with Mann-Whitney $U$ test by boys (Table 3.) and girls (Table 4.).

Table 3. The results of Independent Samples Mann-Whitney U test by boys

\begin{tabular}{|c|l|c|c|c|}
\hline \multirow{2}{*}{ Number of item Item } & $\begin{array}{l}\text { Serbian boys } \\
\text { (Mean score) }\end{array}$ & $\begin{array}{c}\text { Slovakian boys } \\
\text { (Mean score) }\end{array}$ & $\mathrm{p}$ \\
\hline 1 & Handling Operating System (OS) & 3,11 & 2,45 & 0,00 \\
\hline 2 & Word processor & 3,22 & 2,50 & 0,00 \\
\hline 3 & Spreadsheet & 2,78 & 2,07 & 0,00 \\
\hline 4 & Database Management & 2,22 & 1,62 & 0,00 \\
\hline 5 & Multimedia & 2,88 & 2,28 & 0,00 \\
\hline 6 & Software specific to my degree & 2,24 & 1,76 & 0,00 \\
\hline 7 & Using documentary bases (Such as EBSCO) & 2,10 & 1,53 & 0,00 \\
\hline 8 & Web Browsing & 3,46 & 2,99 & 0,00 \\
\hline 9 & Internet Communication & 3,45 & 2,90 & 0,00 \\
\hline 10 & Internet Safety & 2,82 & 2,21 & 0,00 \\
\hline 11 & Website design & 2,16 & 1,53 & 0,00 \\
\hline 12 & Using learning platforms & 1,77 & 1,30 & 0,00 \\
\hline 13 & Image Editing & 2,59 & 2,19 & 0,00 \\
\hline 14 & Video Editing & 2,41 & 1,76 & 0,00 \\
\hline 15 & Creating simulations and animations & 1,92 & 1,32 & 0,00 \\
\hline
\end{tabular}

According to the table (Table 3.) we can find significant differences by every items as sooner. The subjective ICT literacy level of Serbian boys is higher as the Slovakian boys. 
The situation is same by girls too (Table 4.). The Serbian girls achieved significant higher scores by ever items than Slovakian girls. It seems the higher number of ICT lessons have same influence on the ICK literacy level independently from the gender.

Table 4. The results of Independent Samples Mann-Whitney U test by girls

\begin{tabular}{|c|l|c|c|c|}
\hline $\begin{array}{c}\text { Number of } \\
\text { item }\end{array}$ & \multicolumn{1}{|c|}{ Item } & $\begin{array}{c}\text { Serbian girls } \\
\text { (Mean score) }\end{array}$ & $\begin{array}{c}\text { Slovakian girls } \\
\text { (Mean score) }\end{array}$ & $\mathrm{p}$ \\
\hline 1 & Handling Operating System (OS) & 2,35 & 1,75 & 0,00 \\
\hline 2 & Word processor & 2,90 & 2,21 & 0,00 \\
\hline 3 & Spreadsheet & 2,47 & 1,79 & 0,00 \\
\hline 4 & Database Management & 1,93 & 1,50 & 0,00 \\
\hline 5 & Multimedia & 2,35 & 1,84 & 0,00 \\
\hline 6 & Software specific to my degree & 1,98 & 1,65 & 0,00 \\
\hline 7 & Using documentary bases (Such as EBSCO) & 1,99 & 1,60 & 0,00 \\
\hline 8 & Web Browsing & 3,10 & 2,61 & 0,00 \\
\hline 9 & Internet Communication & 3,22 & 2,64 & 0,00 \\
\hline 10 & Internet Safety & 2,53 & 1,88 & 0,00 \\
\hline 11 & Website design & 1,58 & 1,23 & 0,00 \\
\hline 12 & Using learning platforms & 1,64 & 1,26 & 0,00 \\
\hline 13 & Image Editing & 2,57 & 1,93 & 0,00 \\
\hline 14 & Video Editing & 1,77 & 1,47 & 0,01 \\
\hline 15 & Creating simulations and animations & 1,59 & 1,30 & 0,00 \\
\hline
\end{tabular}

\subsubsection{The results of Independent Samples Mann-Whitney $U$ test by gender in Serbia}

The following steps are to see the difference in subjective ICT literacy level by gender in the countries.

We calculated the mean scores by items and also calculated the difference between the students grouped by genders in Serbia. Then we can make analysis process with MannWhitney U test by gender (Table 5.).

Table 5. The results of Independent Samples Mann-Whitney U test by gender in Serbia

\begin{tabular}{|c|l|c|c|c|}
\hline $\begin{array}{c}\text { Number } \\
\text { of item }\end{array}$ & \multicolumn{1}{|c|}{ Item } & $\begin{array}{c}\text { Serbian girls } \\
\text { (Mean score) }\end{array}$ & $\begin{array}{c}\text { Slovakian girls } \\
\text { (Mean score) }\end{array}$ & $\mathrm{p}$ \\
\hline 1 & Handling Operating System (OS) & 3,11 & 2,35 & 0,00 \\
\hline 2 & Word processor & 3,22 & 2,90 & 0,01 \\
\hline 3 & Spreadsheet & 2,78 & 2,47 & 0,01 \\
\hline 4 & Database Management & 2,22 & 1,93 & 0,02 \\
\hline 5 & Multimedia & 2,88 & 2,35 & 0,00 \\
\hline 6 & Software specific to my degree & 2,24 & 1,98 & 0,04 \\
\hline 7 & Using documentary bases (Such as EBSCO) & $\mathbf{2 , 1 0}$ & $\mathbf{1 , 9 9}$ & $\mathbf{0 , 5 5}$ \\
\hline 8 & Web Browsing & 3,46 & 3,10 & 0,01 \\
\hline 9 & Internet Communication & 3,45 & 3,22 & 0,04 \\
\hline 10 & Internet Safety & 2,82 & 2,53 & 0,01 \\
\hline 11 & Website design & 2,16 & 1,58 & 0,00 \\
\hline 12 & Using learning platforms & $\mathbf{1 , 7 7}$ & $\mathbf{1 , 6 4}$ & $\mathbf{0 , 1 6}$ \\
\hline 13 & Image Editing & $\mathbf{2 , 5 9}$ & $\mathbf{2 , 5 7}$ & $\mathbf{0 , 8 4}$ \\
\hline 14 & Video Editing & 2,41 & 1,77 & 0,00 \\
\hline 15 & Creating simulations and animations & 1,92 & 1,59 & 0,00 \\
\hline
\end{tabular}


According to the table (Table 5.) we can find any significant differences in the subjective ICT literacy level of Serbian girls and boys. It means the Serbian girls and boys do not have same subjective ICT literacy level in the higher education, by the big part of items the scores of boys are higher. On other hand the subjective ICT literacy level of Serbian boys is same with Serbian girls by handling "Using documentary bases", "Using learning platforms" and "image editing".

\subsubsection{The results of Independent Samples Mann-Whitney $U$ test by gender in Slovakia}

We calculated the mean scores by items and also calculated the difference between the students grouped by genders in Slovakia.

Then we can made analysis process with Mann-Whitney U test by gender (Table 6.).

Table 6. The results of Independent Samples Mann-Whitney U test by gender in Slovakia

\begin{tabular}{|c|l|c|c|c|}
\hline \multirow{2}{*}{ Number of item } & \multicolumn{1}{|c|}{ Item } & $\begin{array}{c}\text { Serbian girls } \\
\text { (Mean score) }\end{array}$ & $\begin{array}{c}\text { Slovakian girls } \\
\text { (Mean score) }\end{array}$ & $\mathrm{p}$ \\
\hline 1 & Handling Operating System (OS) & 2,45 & 1,75 & 0,00 \\
\hline 2 & Word processor & 2,50 & 2,21 & 0,00 \\
\hline 3 & Spreadsheet & 2,07 & 1,79 & 0,01 \\
\hline 4 & Database Management & $\mathbf{1 , 6 2}$ & $\mathbf{1 , 5 0}$ & $\mathbf{0 , 5 2}$ \\
\hline 5 & Multimedia & 2,28 & 1,84 & 0,00 \\
\hline 6 & Software specific to my degree & $\mathbf{1 , 7 6}$ & $\mathbf{1 , 6 5}$ & $\mathbf{0 , 2 8}$ \\
\hline 7 & Using documentary bases (Such as & $\mathbf{1 , 5 3}$ & $\mathbf{1 , 6 0}$ & $\mathbf{0 , 7 1}$ \\
\hline 8 & EBSCO) & 2,99 & 2,61 & 0,00 \\
\hline 9 & Web Browsing & 2,90 & 2,64 & 0,02 \\
\hline 10 & Internet Communication & 2,21 & 1,88 & 0,00 \\
\hline 11 & Website design & 1,53 & 1,23 & 0,00 \\
\hline 12 & Using learning platforms & $\mathbf{1 , 3 0}$ & $\mathbf{1 , 2 6}$ & $\mathbf{0 , 4 7}$ \\
\hline 13 & Image Editing & 2,19 & 1,93 & 0,03 \\
\hline 14 & Video Editing & 1,76 & 1,47 & 0,00 \\
\hline 15 & Creating simulations and animations & $\mathbf{1 , 3 2}$ & $\mathbf{1 , 3 0}$ & $\mathbf{0 , 8 5}$ \\
\hline
\end{tabular}

According to the table (Table 6.) we can find any significant differences in the subjective ICT literacy level of Slovakian girls and boys. It means the Slovakian girls and boys do not have same subjective ICT literacy level in the higher education. On other hand the subjective ICT literacy level of Slovakian boys higher as the Slovakian girls by handling operating systems, word processing, spreadsheet calculation, multimedia, web browsing, internet communication, internet safety, website design, image and video editing. They have same subjective ICT literacy level by the rest of items.

\section{Conclusion}

In this research we have tried to analyze the subjective ICT literacy level of the Serbian and Slovakian students in the higher education. We have used a self-reported questionnaire with 15 items) and Likert-type rating. 
After the analyzing process we can say the subjective ICT literacy level of Serbian students by every items is higher than Slovakian students.

We have made more analysis by gender by countries. In the following we share the important information connection with it.

We have found significant differences by boys in same case then by countries. It means the subjective ICT literacy level of Serbian boys is higher as the Slovakian boys. The results by girls are the same. It shows the subjective ICT literacy level of Serbian girls is higher than the Slovakian girls in the higher education. The Serbian studenst can take the advantage of the higher ICT lessons from the primary school to the final exam independently from the gender.

We made the analysis by gender in countries too and we have found some interesting thing in that case. The Serbian girls and boys have same subjective ICT literacy level by "Using documentary bases", "Using learning platforms" and "Image editing", by the rest of items the Serbian boys reached higher scores.

The situation was a little bit different in Slovakia. The ICT literacy level of Slovakian boys is higher by handling operating systems, word processing, spreadsheet calculation, multimedia, web browsing, internet communication, internet safety, website design, image and video editing. By the rest of the items we could not find significant difference by gender in Slovakia. We have found more items where was not difference in the subjective ICT literacy level by gender in Slovakia it means the gender-gap is not so big in this country.

The Serbian girls did not have higher subjective ICT literacy level than boys by any items it means in Serbia would be more important to think over the by gender separated ICT education like it works in Germany where it was recognized the girls can catch same result in ITC but they need other teaching methods.

\section{Acknowledgements}

Thank you for the teacher colleagues at University of Novi Sad for the collecting data from the students.

\section{References}

1. G. Kiss, "The survey measuring the informatics skills of the entering Students at Budapest Tech, Bánki Donát Faculty of Mechanical and Safety Engineering", 7th IEEE International Symposium on Intelligent System and Informatics, Subotica, Serbia, 2009, ISBN: 978-1-4244-5348-1, pp:395-397, IEEE Xplore digital library Digital Object Identifier: 10.1109/SISY.2009.5291125

2. G. Kiss, "A comparison of informatics skills by genders of Hungarian grammar school students", 8th International Conference on Applied Informatics, Eger, 2010, ISBN 978989472 3, Vol. 2., pp. $17-27$

3. G. Kiss, "A Comparison of Informatics Skills by schooltypes in the 9-10th grades in Hungary", International Journal of Advanced Research in Computer Science, 2011, Vol.: 2, No. 2, ISSN: 0976-5697, pp. 417-428

4. G. Kiss, "Measuring Student's Computer Science Knowledge at the End of the primary stage in Hungary", 9th IEEE International Symposium on Applied Machine Intelligence and Informatics, Smolenice, Slovakia, 2011, ISBN: 978-1-4244-7428-8, pp. 19-22, IEEE Catalog Number: CFP1108E-CDR, IEEE Xplore digital library Digital Object Identifier: 10.1109/SAMI.2011.5738880;

5. G. Kiss, "Measuring Hungarian and Slovakian Students' IT Skills and Programming Knowledge", Acta Polytechnica Hungarica, Vol. 9., No. 6, 2012, ISSN: 1785-8860, pp. 195-210,

6. Министарство просвете, науке и технолошког развоја (2008): Наставни програм за предмет Од играчке до рачунара за први и други разред основног образовања и васпитања. http://bit.ly/1scrO2j (2014. 03 26.) 
7. Министарство просвете, науке и технолошког развоја (2008): Наставни програм образовања и васпитања за трећи разред основног образовања и васпитања. http://bit.ly/Ke3tHx (2014. 03 26.)

8. Zs. Námesztovszki, „IKT eszközök a Vajdaság iskoláiban”, II. „Trefort Ágoston” Szakmai Tanárképzési Konferencia, Óbudai Egyetem, Trefort Ágoston Mérnökpedagógiai Központ, Budapest. ISBN: 978-615-5018-39-8, pp. 222-233.

9. R. Likert, „A technique for the measurement of attitudes”, Archives of Psychology, 1932, Vol.: 27, No.: 140, pp 44-55

10. S. Jamieson, „Likert scales: how to (ab)use them”, Medical Education 2004; Vol.: 38, pp 12171218

11. W. Boonyasit, „Appropriate statistical analysis for two independent groups of Likert-type data”, Dissertation, American University Washington ,2011

12. J. C. F. De Winter and D. Dodou, „Five-Point Likert Items: t test versus Mann-WhitneyWilcoxon, Practical Assessment", Research \& Evaluation, 2010, Vol.: 15, No.: 11, ISSN: 15317714 